\title{
Thematic Analysis of Patient's Perceived Benefit of Trauma-focused Psychological Treatment
}

\author{
Lina JOVARAUSKAITE ${ }^{\mathrm{a}}$, Paulina ZELVIENE ${ }^{\mathrm{a}, 1}$, Egle MAZULYTE ${ }^{\mathrm{a}}$ \\ ${ }^{a}$ Vilnius University
}

\begin{abstract}
The patients' reported perceived benefit usually differs from the therapist perspective. For this reason, it is important to analyze the clients' point of view to form a better understanding of the therapeutic process. The aim of the current study was to reveal the aspects of the patient's perceived benefit of the trauma-focused therapy. Method. In our qualitative study there were analyzed accounts of 10 interviewers who completed 16 sessions of brief eclectic psychotherapy. The collected material was analyzed using a thematic analysis. Results. The patients perceived benefit of the therapy can be categorized into four domains: the competence of the therapist, therapeutic relationship, changes in psychological well-being, and the therapeutic method.
\end{abstract}

Keywords. Traumatic event, PTSD, trauma-focused treatment, effectiveness.

\section{Introduction}

The question "What was the most important to you during the psychological treatment?" may yield different answers. Understanding the patient's reported perceived therapeutic benefit might be useful for not missing significant moments of the therapy, which potentially may be helpful for the patient. According to the systematic review completed by Timulak (2010), there are clear discrepancies between what clients and therapists find helpful in the therapy. To explore the patient's perceived benefit in therapy, Timulak (2010) collected 41 studies analyzing various ways of treatment, based on different theoretical approaches (humanistic, psychodynamic, interpersonal, cognitive-behavior, eclectic, etc.). The results have shown that clients value both the therapeutic relationship (e. g., reassurance, understanding, and personal contact) and various session outcomes (e. g., insight, relief, behavior changes, new feelings, and empowerment). It is important to note that clients prefer relational and emotional aspects of therapy, whereas therapists are more likely to value its cognitive parts. This potential discrepancy may negatively affect the therapy due to the possibility of missing some important aspects of the therapeutic process.

Clarke and colleagues (2004) examined five participants diagnosed with a major depression episode and completed 12-20 sessions of cognitive therapy, and after treatment they were asked about what in their opinion was important in helping them to change. The clients' perceived therapeutic benefit was linked to listening to the therapist (at first, clients expressed resistance and fear, then engagement in therapy, and finally feeling safe and supported), a specific technique and procedures (theoretical model, dealing with thoughts, understanding core beliefs, testing things out) and finding some ways to feel comfortable with the self (changes in everyday behavior, emotions, letting things go, positive outcomes in mood, thoughts, behavior, physical appearance).

Carey and colleagues (2007) carried out a qualitative research analyzing the process of change which is the main goal in every type of psychotherapy. In their qualitative study, 27 interviewers were asked to describe how the changes occurred. Six basic themes emerged from participants' answers. The first category revealed the importance of motivation and readiness for change. Participants were dissatisfied with their current situation and felt the need for a new direction. The second category was about the perceived aspects of the self. Participants mentioned their personality type, traits, traumatic experience as factors encouraging for change. Specific therapeutic interventions and strategies in the therapy were also important. Due to the specific therapeutic interventions such as relaxation, diaries and activity charts, participants were able to control their situation. The ability to learn was one of the key factors for change. Patients appreciated the opportunity to get a new perspective of the current situation, self, and the potential reasons for the problems. The fifth category reflected the importance of interaction with therapists. Their nonjudgmental position was valued highest. Having a non-biased opinion and no personal relationship with clients were considered beneficial by the participants of thes study. They also indicated the supportive role of the therapist. Despite seeing the therapist as a necessary part of the therapy, participants highlighted their own efforts. In the last category, participants mentioned the huge relieving effect of talking, sharing emotions and experience. 


\section{Method}

\subsection{Participants and procedures}

Nine Lithuanian women and one man aged 20 to 55 years $(M=32.30 ; S D=11.41)$ participated in the current study. All participants had been exposed to various traumatic events, such as sexual abuse, traffic accident, suicidal events, and were experiencing clinically significant PTSD symptoms assessed by the Clinician-Administered PTSD Scale for DSM-5 (CAPS) (Weathers et al., 2013). The average time since the traumatic event was 6 years, ranging from 2 months to 20 years. Each participant received 16 weekly sessions of Brief Eclectic Psychotherapy for PTSD (BEPP) consisting of five stages: psychoeducation, imaginal exposure, writing tasks and mementos, meaning and integration, and the farewell ritual (Gersons, Carlier, Lamberts, \& van der Kolk, 2000), provided by trained psychologists with at least ten years of professional experience. Thirty percent of participants were taking the prescribed medication during the therapy. The post-treatment evaluation revealed that none of participants had clinically significant PTSD symptoms after the treatment.

One week after the BEPP treatment, participants were interviewed by clinical psychologists other than those who provided the treatment and in different setting than the treatment had been provided. A single item question was used to measure a client's perceived significant moments of the therapy. Participants were asked to answer freely and as much as they wanted to the question: "What was most important for you during the psychological treatment?". The collected material was analyzed using a thematic analysis (Braun \& Clarke, 2006) by two researchers.

\section{Results}

Four basic themes were derived from the qualitative data: "therapeutic relationship", "competence of the therapist", "therapeutic method", "changes in well-being".

Therapeutic relationship. Participants indicated various aspects related to the therapeutic relationship as one of the most important features of the therapy. Some participants said: "For the first time I felt listened to and well understood", the "psychologist... is here to listen, to support,... the method isn't important any more... but it is important that you have been listened to". The other told that "the connection with the psychologist... a person who is warm, nice and prepared to help me". "No quick judgment, no diagnosis... but communication... no stigmatization", "the psychologist didn't blame me... she was there for me".

Competence of the therapist. According to interviewers, competence, particular personal features of the therapist are also crucial. One of the most important characteristics of the therapist was professional competence: "their professionalism", "the psychologist's personality, a high professional level is very important...", "the psychologist explains everything clearly".

Therapeutic method. Participants also identified some characteristics and elements of the therapeutic method, in this case the BEPP therapy. They mentioned the task to write a letter - "it was some kind of a let-off steam", mementos, farewell ritual and imaginal exposure - "talking about memories ... repeating”, " although I didn't like it, it worked...", "it was difficult at first, then it became easier". One of the interviewers highlighted specific features of the therapy as helpful - "the frequency of sessions was comfortable, with the possibility to choose the time, the format of the therapy".

Changes in well-being revealed the importance of positive outcomes in the emotional area and particular moments of traumatic experience integration. The subcategory Decreased emotional reactions contains answers such as "Most important was to feel less tension... not to feel pain", "reducing guilt", "to improve psychological well-being and to bring it back to normal". The last subcategory was called Integration. Some participants told: "I have accepted that it happened and there is nothing I can do about it... there is no reason to be angry", I should "to settle down and to accept what happened". Another interviewer mentioned "the ability to comprehend, with the help of the therapy, that my mother's courses are separate from me... to realize that they were my mother's even if they still influence me".

\section{Discussion}

The perceived benefit from patients' perspective in the therapy may enrich the knowledge about the benefits that the therapeutic process can offer. The aim of the current study was to elucidate the patient's perceived benefit from the therapeutic experience. Significant points of trauma-focused therapy were reported by patients. From patients' perspective, the most important moments of the therapy can be grouped into four domains: competence of the therapist, therapeutic relationship, changes in psychological well-being, and the therapy method. The first three categories reflect more affective domains, and the last one represents the behavioral elements of the therapy. According to the results of our study, participants mentioned the specific aspects of the therapeutic relationship and competence of the therapist. This reflects findings of other qualitative studies (Carey et al., 2007; Clarke et al., 2004; 
Binder et al., 2009). In Timulak's (2010) opinion, interpersonal aspects of significant events in the therapy can be much more important than the therapist thinks. For this reason, in the clinical practice, it is worth paying attention to the patients' perceived benefit of the ongoing therapy, to discuss it and invite clients to be active participants of therapeutic process. The domain of changes in psychological well-being represents the aspects of emotional relief and finding a new perspective. This is similar to what Clarke et al. (2004) described as being comfortable with the self, as Timulak (2010) called in-session outcomes or "learning" in the study of Carey and colleagues (2007). According to Paulson, Truscott, and Stuart (1999), attending to the emotional experience of the clients gives an opportunity to reorganize their perception of reality, which can lead to cognitive and behavioral changes. The last category - method - shows that clients identify specific elements of the BEPP therapy as important. This confirms the idea that clients value both specific cognitive interventions and more general elements of psychological treatments (e. g., personal contact) (Clarke et al., 2004). The importance of procedures and tools are also highlighted in the study by Carey and colleagues (2007).

There are several limitations to be considered in our study. Firstly, the small sample size could have an effect on the results. Secondly, all our participants were women and findings of our study cannot be generalized for men; thus, further studies with a larger and mixed gender sample sizes could reveal more information about the perceived benefits of trauma-focused psychotherapy.

\title{
4. Conclusions
}

The current qualitative study suggests that the patients-perceived benefit of a brief trauma-focused psychotherapy is related to the competence of the therapist, the aspects of the treatment method, therapeutic relationship, and individual changes in clients' psychological well-being.

\section{Acknowledgments}

This research was funded by a grant MIP-011/2012 from the Research Council of Lithuania. We are grateful for Dr. Evaldas Kazlauskas, Dr. Migle Dovydaitienè and dr. Paulius Skruibis for a valuable contribution to this study.

\section{Teminè analizè: kliento suvokta nauda gaunant specializuotą psichotraumatologinę pagalbą}

\author{
Lina JOVARAUSKAITÉ ${ }^{\mathrm{a}}$, Paulina ŽELVIENE் $\dot{\mathrm{E}}^{\mathrm{a}, 1}$, Egle MAŽULYTÉ $^{\mathrm{a}}$ \\ ${ }^{a}$ Vilniaus universitetas \\ ${ }^{I}$ Paulina Želviene: p.zelviene@gmail.com
}

Ivadas. Dažnai klientų ir terapeutų požiūriai ị tai, kas yra naudinga terapiniame procese, nesutampa. Dèl šios priežasties, siekiant gilesnio terapinio proceso suvokimo, naudinga analizuoti minètus aspektus ne tik iš terapeuto, bet ir iš kliento perspektyvos Tikslas - atskleisti kliento suvoktos naudos aspektus gaunant psichotraumatologinę pagalbą. Metodas. Tyrime dalyvavo 10 asmenų, iš kurių buvo imami interviu praejus savaitei po 16 trumpalaikès eklektinès psichotraumatologinès terapijos sesijų. Interviu metu gauti duomenys buvo analizuojami pasitelkus teminę analizę. Rezultatai. Klientų suvokiama nauda terapijoje yra susijusi su keturiomis kategorijomis: terapeuto kompetencija, terapiniu santykiu, metodu ir psichologinès savijautos pokyčiais.

Pagrindiniai žodžiai. Potrauminio streso sutrikimas, trauma, terapijos efektyvumas.

\section{Literature}

Binder, P. E., Holgersen, H., \& Nielsen, G. H. (2009). Why did I change when I went to therapy? A qualitative analysis of former patients' conceptions of successful psychotherapy. Counselling and Psychotherapy Research, 9 (4), 250-256.

Carey, T. A., Carey, M., Stalker, K., Mullan, R.J., Murray, L.K., \& Spratt, M.B. (2007). Psychological change from the inside looking out: A qualitative investigation. Counselling and Psychotherapy Research, 7, 178-187.

Clarke, H., Rees, A., \& Hardy, G. E. (2004). The big idea: Clients' perspectives of change processes in cognitive therapy. Psychology and Psychotherapy: Theory, Research and Practice, 77, 67-89.

Gersons, B. P., Carlier, I. V., Lamberts, R. D., \& van der Kolk, B. A. (2000). Randomized clinical trial of brief eclectic psychotherapy for police officers with posttraumatic stress disorder. Journal of Traumatic Stress, 13 (2), 333-347.

Paulson, B. L., Truscott, D., \& Stuart, J. (1999). Clients' perceptions of helpful experiences in counselling. Journal of Counseling Psychology, 46, 317-324.

Timulak L. (2010). Significant events in psychotherapy: An update of research findings. Psychology and Psychotherapy: Theory, Research and Practice, 83 (4), 421-447. 